\title{
Correction to: Qualities of Teacher Effectiveness in Delivering School-Based Mental Health Programs: The Relevance of Emotional Intelligence
}

Ashley Vesely, Evelyn Vingilis, Donald H. Saklofske, and Alan W. Leschied

\section{Correction to:}

Chapter 10 in: A. W. Leschied et al. (eds.), Handbook of School-Based Mental Health Promotion, The Springer Series on Human Exceptionality, https://doi.org/10.1007/978-3-319-89842-1_10

The book was inadvertently published with an incorrect spelling of the author's name in Chapter 10 as Eveyln Vangelis whereas it should be Evelyn Vingilis.

The updated online version of this chapter can be found at https://doi.org/10.1007/978-3-319-89842-1_10 